\title{
Modelling of a Solid Oxide Fuel Cell for Integrated Coal Gasification Hybrid Power Plant Simulation
}

\author{
Dr.-Ing. M. Krüger \\ DLR (German Aerospace Centre), Institute of Technical Thermodynamics, \\ Pfaffenwaldring 38-40, 70569 Stuttgart, Germany \\ E-mail: michael.krueger@dlr.de
}

Received 17 October 2014, Revised 11 February 2015, Accepted 13 February 2015

\begin{abstract}
Now and in the mid-term future, coal remains an important energy source for electricity generation for reasons of energy supply security and economics. The expectation for low $\mathrm{CO}_{2}$-emissions and high plant efficiencies make solid oxide fuel cells an essential part of numerous innovative power plant concepts. For that reason, simplified and flexible models for solid oxide fuel cells are needed, which can be implemented easily in complex power plant system simulations. A model for a tubular solid oxide fuel cell based on a semi-empirical approach has been developed. The created model is successfully validated with operating data of demonstration plants published in literature. For the target application in a hybrid power plant with high temperature fuel cells, a parametric study of fuel gas composition, operating pressure and temperature, fuel utilization and electrical power density is presented. By means of these, the model of the fuel cell is qualified for implementation in hybrid power plants system models. Additionally, characteristic diagrams obtained by variation of the operating pressure and the fuel utilization are discussed. With the help of the diagrams, the electric and energetic performance of the SOFC over a wide range of these parameters is described by isolines for discrete values of the electrical efficiency and voltage of the fuel cell.
\end{abstract}

Keywords: Modelling; SOFC; tubular cell; coal gasification; IGFC; hybrid power plant.

\section{Introduction}

In order to satisfy the permanently increasing worldwide energy demand, various energy sources need to be combined. Fossil energy sources contribute approx. $80 \%$ to the worldwide energy supply, whereas about a quarter of it is gained from coal. For increasing efficiency and introduction of $\mathrm{CO}_{2}$-sequestration into the market, the optimization or retrofitting of existing power plants as well as the development of innovative power plant concepts are necessary for survival on the market in the mid- to longterm range. The technology of fuel cells offers the opportunity of improved overall efficiencies and good options for the integration of $\mathrm{CO}_{2}$-sequestration. In [1] and [2], innovative hybrid power plants integrating high temperature fuel cells have been developed. These plants are very complex due to a high level of thermal and material integration.

For their simulation, simplified process models are needed, which would allow for flexibility in operating conditions and parametric studies. At the same time, the requirement for reproducing the operating characteristics of installed facilities with a sufficiently high model accuracy has to be fulfilled.

For the first time, in this article a model of a special tubular SOFC-type usable for power plant applications fueled with coal gas under pressurized conditions is presented, which fulfil these requirements mentioned above and is validated with operating data of demonstration plants published in literature.

In the following, the required fundamentals of SOFC, the created model itself, its validation and use for a parametric study regarding the target application in integrated coal gasification hybrid power plants are described.

\section{Fundamentals of Fuel Cells}

The highest possible voltage in a fuel cell under fixed boundary conditions of gas composition, temperature and pressure is the Nernst voltage or open circuit voltage $U_{N}$. It describes the reversible operation of fuel cells and is defined by the Nernst Equation, see Eq. (1).

$U_{N}=-\frac{\Delta^{R} G}{n F}-\frac{R T}{n F} \cdot \ln \left(\prod_{i}\left(\frac{p_{i}}{p^{0}}\right)^{v_{i}}\right)$

where $U_{N}$ is the Nernst voltage, $\Delta^{R} G$ is the enthalpy of reaction, $n$ is the number of electrons exchanged during reaction, $F$ is the Faraday constant, $R$ is the universal gas constant, $T$ is the operating temperature of the fuel cell, $p_{i}$ is the partial pressure of component $i, p^{0}$ is the reference pressure (at standard conditions) and $v_{i}$ is the stoichiometric coefficient of component $i$.

In practice, however, lower voltages are achieved. These are caused by irreversibilities, often known as overvoltage or losses, and are due to the operation, the materials used and the construction of the fuel cell [3]. In particular, these are $[4,5]$ :

- activation losses,

- fuel crossover and internal voltage losses,

- ohmic losses,

- concentration polarization and mass transfer losses. 
An important parameter of fuel cells is the effective electrical efficiency $\eta_{\text {el,cell }}$, indicating the degree of conversion of the chemically bound energy of the fuel into electricity, see Eq. (2).

$\eta_{e l, c e l l}=\frac{P_{e l, c e l l}}{\dot{m}_{F G, i n} H_{u, F G}}$

where $P_{e l, c e l l}$ is the electrical power of a single cell, $\dot{m}_{F G, i n}$ is the mass flux of fuel gas at cell inlet and $H_{u, F G}$ is the net calorific value of fuel gas.

If the fuel cell is combined with other energy converters distributing electricity, it is advisable to use an electrical efficiency that only considers the reacted fuel gas. Here, this is called the effective electrical net efficiency $\eta_{\text {el,cell,net }}$ and is defined by Eq. (3).

$\eta_{e l, c e l l, n e t}=\frac{P_{e l, c e l l}}{\eta_{F U} \dot{m}_{F G, \text { in }} H_{u, F G}}$

where $\eta_{F U}$ is the fuel utilization.

In this, the proportion of electrochemically unreacted fuel gas has to be taken into account. This is done with the fuel utilization $\eta_{F U}$, which is calculated according to Eq. (4), the ratio of electrochemically utilized supplied fuel gas flux to the fed fuel gas flux.

$\eta_{F U}=\frac{\dot{m}_{F G, u t}}{\dot{m}_{F G, \text { in }}}=1-\frac{\dot{m}_{F G, \text { out }}}{\dot{m}_{F G, \text { in }}}$

where $\dot{m}_{F G, u t}$ is the electrochemical utilized mass flux of fuel gas and $\dot{m}_{F G \text {,out }}$ is the mass flux of fuel gas at the cell outlet.

The development of fuel cells has spawned many different fuel cell systems. For fuel cell systems as a part of hybrid power plants with integrated coal gasification, a high tolerance towards carbon monoxide $\mathrm{CO}$ is essential due to the high content of this species in coal gas. Of the technically relevant fuel cell systems, the high temperature fuel cells exclusively come into consideration. Here, the solid oxide fuel cells (SOFC) are used, because of the high efficiency potential and the extreme flexibility in terms of fuel choice, including coal gas [6-9], biogas [10-13], landfill gas $([14,15])$, mine gas [16-18] and sewage gas $[19,20]$. Because of the decision in favor of SOFC, the next sections deal with this fuel cell type.

\subsection{Solid Oxide Fuel Cells}

When hydrogen is used as the fuel, the chemical reaction according to Eq. (5) takes place at the anode and the reaction following Eq. (6) at the cathode. The overall reaction is then given by Eq. (7).

$$
\begin{aligned}
& \mathrm{H}_{2}+\mathrm{O}^{2-} \rightarrow \mathrm{H}_{2} \mathrm{O}+2 \mathrm{e}^{-} \\
& \mathrm{O}_{2}+4 \mathrm{e}^{-} \rightarrow 2 \mathrm{O}^{2-}
\end{aligned}
$$

$$
\mathrm{H}_{2}+\frac{1}{2} \mathrm{O}_{2} \rightarrow \mathrm{H}_{2} \mathrm{O}
$$

If carbon monoxide is a component of the fuel gas, the water-gas-shift-reaction takes place; see Eq. (8).

$\mathrm{CO}+\mathrm{H}_{2} \mathrm{O} \rightarrow \mathrm{H}_{2}+\mathrm{CO}_{2}$

Since there are no restrictions in the SOFC regarding carbon monoxide, additional hydrogen can be produced in this manner. Due to the high operating temperature, the internal reformation of hydrocarbons according to the general reaction (9) is possible.

$\mathrm{C}_{x} \mathrm{H}_{y}+\mathrm{x} \mathrm{H}_{2} \mathrm{O} \rightarrow \mathrm{xCO}+\left(\mathrm{x}+\frac{\mathrm{y}}{2}\right) \mathrm{H}_{2}$

The reaction (9) is generally not in chemical equilibrium, since the carbon monoxide reacts further in accordance with reaction (8). The direct oxidation of carbon monoxide and hydrocarbons might also be possible, but the water-gas-shift- and the internal reforming reactions run much faster [4,21].

Three designs are developed to realize SOFC: the planar, the monolithic and the tubular concept. For systems with a large power output, the tubular design is in a more advanced stage of development compared to the other two configurations [22,23]. Many problems of the other constructions, such as sealing and thermal stresses, do not occur in tubular SOFCs due to design reasons [22]. The most developed (according to [4, 24, 25]) and the best (according to [26] construction is the sealless cell design of cylindrical tubes by Siemens. This type of cell has been tested extensively in terms of long-term stability and thermal cyclability: single cells have been in operation more than 69000 test hours; more than 100 thermal cycles have been verified [27]. This type of cell is used in this work. Detailed descriptions can be found elsewhere [2830]. The dependence of the voltage-current-characteristic on the operating temperature and pressure at defined conditions was published in [30]. Thus, the single cells are characterized electrochemically over the operating ranges of these two parameters.

\subsection{Important Operational Aspects and Problems}

The exothermic chemical reactions occurring in SOFCs produce heat, which has to be conducted away from the cell. The level of the maximum permissible temperature gradient is limited by the construction of the SOFC in ceramic layers [26]. External cooling systems with liquid heat transfer media are complicated to implement and the cooling is done in the actual SOFC using excess oxidant at the cathode [31]. To prevent material damage, the temperatures of the inlets of the SOFC have to be greater than a certain value [26]. A temperature difference between the inlet streams and the SOFC of $200 \mathrm{~K}$ is assumed, as used in [20,32-34].

Due to carbonaceous species of $\mathrm{CO}, \mathrm{CO}_{2}$ and $\mathrm{CH}_{4}$ within the coal gas, the following chemical reactions are possible at the anode to form elementary carbon, respectively soot [35]: 


$$
\begin{aligned}
& \mathrm{CH}_{4} \leftrightarrow \mathrm{C}+2 \mathrm{H}_{2} \\
& 2 \mathrm{CO} \leftrightarrow \mathrm{C}+\mathrm{CO}_{2}
\end{aligned}
$$

$\mathrm{CO}+\mathrm{H}_{2} \leftrightarrow \mathrm{C}+\mathrm{H}_{2} \mathrm{O}$

$\mathrm{CO}_{2}+2 \mathrm{H}_{2} \leftrightarrow \mathrm{C}+2 \mathrm{H}_{2} \mathrm{O}$

According to the principle of Le Chatelier, the decomposition of methane, see Eq. (10), is favored at low pressure and at high temperature due to its endothermic character. Larminie and Dicks [5] note a temperature limit of $650{ }^{\circ} \mathrm{C}$ if air and steam are absent. The other three chemical reactions are exothermic and thus the equilibrium is shifted to the products. The same applies if the pressure is high. Besides decomposition of methane, the Boudouard reaction according to Eq. (11) is mentioned in literature to be the main reaction of formation of carbon at the SOFC anode. This reaction occurs primarily below $700{ }^{\circ} \mathrm{C}$, as Rechenauer and Achenbach [36] note.

In practice, steam is added to the clean gas flow to favorably influence the equilibrium position and finally to prevent soot formation. Furthermore, the addition of steam enables the methane reformation according to Eq. (9) and the heterogeneous water gas shift reaction - the return reaction of Eq. (12), so that the formation of carbon monoxide and hydrogen from methane and from possibly formed carbon are encouraged. Different values for a steam to carbon ratio $S / C$ are suggested in literature. In practice, values typically in the range $2 \leq S / C \leq 3$ are set at the inlet of the cells to prevent soot formation with certainty, as Larminie und Dicks [5] note.

\section{Modelling of SOFC in Literature}

The objective in modelling a SOFC within this work is to get a model that describes the chemistry and electrochemistry at the SOFC with sufficient accuracy, so that the calculation of the electrical and chemical performance and their impact on the thermodynamic states and gas compositions at the outlet of the electrodes is possible.

Modelling of SOFC is a widely discussed topic in literature. General overviews of modelling are given in [3739]. Only the sources of literature that describe steady, zero-dimensional models, which allow for the study of performance and system aspects of tubular cells, stacks and systems are considered in more detail here.

A literature review of modelling work with steady state and zero-dimensional resolution can be found elsewhere [40-42]. In the following, analytical and semi-empirical models are described briefly.

Analytical models calculate the electrochemical behavior of the SOFC by using the equations listed in section 2.1. The starting point is the Nernst Equation (1), from which the activation, ohmic and concentration losses are deduced. Energy and material balances for the anode and cathode are set globally and the chemical reactions are generally considered as being in equilibrium. Examples for analytical models are the work of Cali et al. [43], Costamagna et al. [44], Lazzaretto et al. [45] and Lisbona and Romeo [46].
Semi-empirical models differ from analytical models primarily in the methodology for calculating the electrochemical behavior of the SOFC. The basis of these are voltage-current characteristics or operating points, which have been obtained by measurements under defined reference conditions. In case of deviating operating conditions, semi-/empirical correction terms are used. The models obtained that way are able to reproduce the global electrochemical behavior of fuel cells of a specific type with good accuracy. Examples of semi-empirical models are the work of Campanari [47], Cocco and Tola [48], Hacker et al. [49] and Zhang et al. [50].

\section{Created Model of a Tubular SOFC \\ 4.1 Approach}

The model developed in this study is based on the work of Campanari [47] and Zhang et al. [50]. However, since significant changes were implemented, the model is described completely here. The key features of the model are:

- intended use in large, thermally and materially highly integrated systems,

- simulation of stacks consisting of tubular cells of the sealless cell design of Siemens,

- steady state,

- zero-dimensional,

- semi-empirical approach using:

$\circ$ a voltage-current characteristic curve as a reference, measured at precisely defined conditions, , in particular the curve shown in [30] at an operating temperature of $1000^{\circ} \mathrm{C}$,

- semi-empirical correlations based on Nernst voltage in case of deviating operating conditions published in [30] with regard to:

- operating temperature,

- operating pressure,

- fuel gas composition,

- oxidizing agent composition.

\subsection{Assumptions and Restrictions}

1. Each cell operates identically. Simulation of an individual cell can be used representatively to calculate the performance of the entire stack. [47, 50-54]

2. The fuel cell is isothermal, i.e. the solid has uniform temperature. [44], [46-48, 50, 54-58]

3. The preheating of the feed gases is adjusted so that the gas temperatures at the inlet of the anode and cathode are equal. [47,50,59]

4. The amount of excess air is regulated to get the same temperature level of cathode outlet gas as anode outlet gas. [46,47,50,59,60]

5. The temperature difference between the solid and gas outlet is assumed to be constant. [47,50]

6. Hydrogen is the only component that reacts electrochemically. Carbon monoxide only reacts indirectly by the water-gas-shift-reaction, see Eq. (8), where hydrogen is produced, which reacts electrochemically. [44,46,47,50,51,56,57,59,61,62]

7. As chemical reactions, only the oxidation of hydrogen, see Eq. (7), and the water-gas-shiftreaction, see Eq. (8), take place. All substances not included in these reactions are assumed to be inert. 
This also applies to methane because it is only present in negligible quantities in coal gas. [53,62]

8. The reaction rates of the admitted reactions either, as in the case of the oxidation of hydrogen, or in the case of water-gas shift reaction in the presence of the catalyst - are so high that it can be assumed that the achievement of a simultaneous state of equilibrium within the reactor volume is a good approximation. The gas mixture at the outlet of the anode has this composition. [44,46,47,50,51,53,55,56,59-61]

9. The amount of pressure drop percentage is dependent on the level of the operating pressure. $[47,48,50,51,55,60,63]$

10. The amount of heat loss is a percentage of the product of calorific value and mass flow (fuel capacity) of the supplied reacted clean gas. [46-48, 50]

11. The electrodes are equi-potential surfaces. The electric potential can be determined by average figures of the extremes (inlet and outlet). $[51,53,56,61,64,65]$

\subsection{Implementation in the Simulation Program}

The implementation of the model of a SOFC stack in the process modeling environment Aspen Plus ${ }^{\mathrm{TM}}$ is based on the simulation of Zhang et al. [50]. The implemented simulation flow diagram of the SOFC stack is shown in Figure 1 and in the following, the model will be explained on the basis of the ASPEN Plus ${ }^{\mathrm{TM}}$ components and settings.

In the flow diagram, the already integrated preheating of the input streams by the residual gas streams is also shown, which is an integrated feature of the used SOFC type. In addition to the actual components, a parallel control unit is shown. Here, it is calculated if the gas at the anode inlet has a composition that holds the risk of soot formation at the present process conditions. Before this aspect is discussed, the actual SOFC model is discussed at this point.

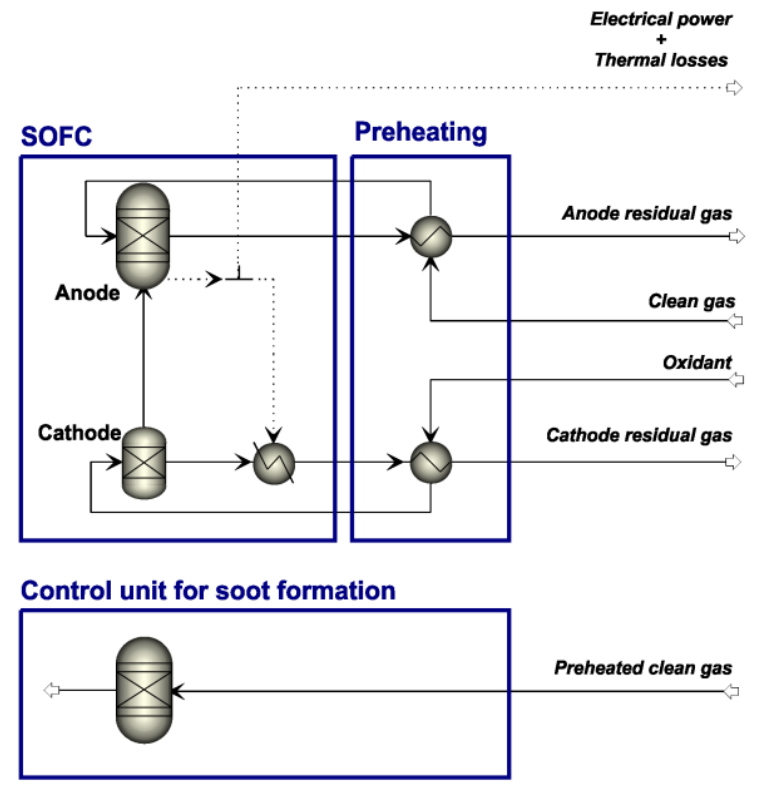

Figure 1. Flow diagram of the SOFC stack.

The preheating of the streams prior to entering the electrode channels by the corresponding residue gas streams is modelled by two HeatX counte r-current heat exchangers. The outlet temperature of the cold stream is defined as a parameter; the absolute value is calculated in relation to the operating temperature of the SOFC by subtracting the tolerable temperature difference between the SOFC solid state and the input stream from the operating temperature. Furthermore, a minimum temperature difference of $20 \mathrm{~K}$ between the respective two streams in the heat exchangers and a pressure loss, which is calculated in an absolute percentage of the inlet pressure of the respective gas flow, are assumed.

The cathode is made with a separator Sep, in which the required oxygen ions for the oxidation of the hydrogen will be separated. The required amount is calculated according to Eq. (14).

$\dot{N}_{\mathrm{O}_{2}, \text { req }}=0.5 \cdot \eta_{\mathrm{FU}} \cdot\left(\dot{N}_{\mathrm{H}_{2}, \text { anodein }}+\dot{N}_{\mathrm{CO}, \text { anodein }}\right)$

where $\dot{N}_{\mathrm{O}_{2} \text {,req }}$ is the required molar flow oxygen, $\dot{N}_{H_{2} \text {,anodein }}$ is the $\mathrm{H}_{2}$ molar stream at anode inlet and $\dot{N}_{\text {CO,anodein }}$ is the CO molar stream at anode inlet.

The anode is modelled as an isothermal equilibrium reactor RGibbs. The heat released by the chemical reactions taking place in the reactor is distributed in a heat flow divider FSplit in a proportion that represents the electric power and the heat losses and in a fraction to be conducted away. The latter is fed to the cathode residual gas stream via a heater. The cathode mass flow is adjusted by a Design Spec so that the outlet temperature of the heater corresponds to the temperature of the anode residual gas. The pressure drop in the cathode and anode will be considered in the same manner as discussed before.

The calculations for all electrochemistry of an SOFC stack, in particular the amount of fuel required, are performed in a calculator. The calculation algorithm of the program is listed in the appendix.

The efficiencies are calculated and outputted according to Eq. (2) and (3). The calculated actual electric power is received in the adjustment of the heat flux fractions of the previously mentioned heat flow divider FSplit. The setting is a Design Spec. In addition, the thermal losses of the SOFC stacks $\dot{Q}_{\text {loss,SOFC }}$ are calculated according to Eq. (15).

$\dot{Q}_{\text {loss }, \text { SOFC }}=e_{\text {loss }} \cdot \eta_{F U} \cdot \dot{m}_{\text {cleangasstack }} \cdot H_{u, \text { cleangas }}$

where $e_{\text {loss }}$ is the loss factor, $\dot{m}_{\text {cleangasstack }}$ is the mass flow of clean gas in the stack and $H_{u, \text { cleangas }}$ is the net calorific value of the clean gas.

The prevention of soot formation by the addition of significant amounts of water vapor to the clean gas flow is the current procedure for small systems. It is not practical for large power plants. So, a thermodynamic approach is used for the simulations, which was proposed by Larminie and Dicks [5] and is also used in other works [66], [67], [68]. The approach provides, in a first step, for calculation of the chemical equilibrium at the inlet of the anode due to the prevailing conditions - chemical composition, temperature and pressure. The resulting equilibrium constants for the soot formation reactions, see Eq. (10) to 
(13), are compared in a second step with the thermodynamic equilibrium constants. If the calculated equilibrium constants are greater than the thermodynamic, soot formation can be thermodynamically excluded.

The implementation of the first step in the simulation program is provided by a control unit for soot formation action arranged in parallel to the SOFC stack. This consists, as shown in Figure 1, of an equilibrium reactor RGibbs and an input and an output stream. With the help of a data transfer unit transfer, the input stream is the same as the flow in the anode and the conditions prevailing in the reactor are identical to the conditions at the inlet of the anode. The calculated outlet stream has the equilibrium composition at the inlet of the anode. The second step is performed in a calculator. Here, the resulting equilibrium constants are first calculated based on the partial pressures in the outlet of the components included in the Eq. (10) to (13). The thermodynamic equilibrium constants are interpolated linearly based on tables from [69]. If the calculated equilibrium constant of the mentioned reactions is lower than the thermodynamic equilibrium constant, the simulation is aborted with an error message. In this way, the risk of soot formation is continuously checked during the simulation of SOFC stacks.

\section{Model Validation}

More reliable published data from single cells or stacks of this special fuel cell type are not available. Therefore, the validation is restricted to the available operating data of realized complete fuel cell power plants. These also provide information about the accuracy of the modelling of the single component. For this, only data of natural gaspowered SOFC power plants are available. Since these systems are composed of many additional peripheral components, such as pre-reformer, ejector and afterburner, the SOFC model must be extended by these components. Thus, the validation process also includes uncertainties caused by modelling this periphery; it is discussed elsewhere in detail [2]. In Table 1, general boundary conditions for the validation of the model of a natural gaspowered SOFC power plant are listed.

Krumbeck [72] reports an electrical gross efficiency of about $55 \%$ at a DC power of about $129.5 \mathrm{~kW}$ of a SOFC power plant operating under atmospheric pressure with an net electrical power of $100 \mathrm{~kW}$. However, no any further boundary conditions at which this value is reached are provided. When the in Table 1 listed boundary conditions and the DC power of $129.5 \mathrm{~kW}$ are set as input values for the simulation, an electrical gross efficiency of about $56.3 \%$ is obtained. Thus, the global accuracy of the modeling is confirmed.
Appropriate detailed operation data are published by Cali et al. [43] and Campanari and Iora [73]. These data were also gathered from a SOFC power plant operating under atmospheric pressure with an electrical nominal power of $100 \mathrm{~kW}$. Furthermore, Campanari and Iora have published operating data of a SOFC micro-gas turbine hybrid power plant with an electrical nominal power of $300 \mathrm{~kW}$, which are also suitable for validation.

Table 1: Boundary conditions for validation using the model of a natural gas-powered SOFC power plant.

\begin{tabular}{l|l|l}
\hline Boundary condition & Value & Ref. \\
\hline SOFC: & 1152 & \\
Number of cells & $1000{ }^{\circ} \mathrm{C}$ & {$[70]$} \\
Operating temperature & 1.08 bar & {$[71]$} \\
Operating pressure & $90{ }^{\circ} \mathrm{C}$ & {$[47]$} \\
Temperature difference between & & \\
SOFC solid to gas outlet & 0.85 & {$[47]$} \\
Fuel utilization & $2 \%$ & {$[47]$} \\
Heat losses & & \\
\hline Afterburner: & $99.5 \%$ & {$[47]$} \\
$\quad$ Efficiency & & \\
\hline Air: & $20 \mathrm{~K}$ & \\
Minimum temperature difference & & \\
$\quad$ while air preheating & $630{ }^{\circ} \mathrm{C}$ & {$[70]$} \\
$\quad$ Inlet temperature & & \\
\hline Natural gas: & & {$[47]$} \\
$\quad$ Composition in mol-\%: & & \\
$\quad$ CH $\mathrm{H}_{4} 81.3, \mathrm{C}_{2} \mathrm{H}_{6} 2.9, \mathrm{C}_{3} \mathrm{H}_{8} 0.4$, & & {$[47]$} \\
$\quad \mathrm{C}_{4} \mathrm{H}_{10} 0.2, \mathrm{CO}_{2} 0.9 ; \mathrm{N}_{2} 14.3$ & & \\
Inlet pressure to $\mathrm{SOFC}$ & 3 & \\
operating pressure & & \\
Inlet temperature & & \\
Steam to carbon molar \\
flow ratio $S / C$
\end{tabular}

The comparison between the operating data from [43] and the results of the simulation are listed in Table 2. Three different operating points are considered for this purpose, which differ in modeling by the input values for the DC electrical power $P_{e l, D C}$. Deviating from Table 1, different working temperatures $\vartheta_{S O F C}$ are taken as input. Results of the simulation appropriate for the validation are the fuel gas mass flow $\dot{m}_{B G}$, the cell voltage $U_{\text {cell }}$ and the current density $i_{\text {cell. }}$. For all variables, a good match is observed.

Table 2. Comparison Between the Operating Data from [43] and the Results of the Simulation Using the Model of a Natural Gas-Powered SOFC Power Plant.

\begin{tabular}{lccccccc}
\hline \multirow{2}{*}{ Parameter } & \multirow{2}{*}{ Unit } & \multicolumn{2}{c}{$118.0 \mathrm{~kW}$} & \multicolumn{2}{c}{$127.4 \mathrm{~kW}$} & \multicolumn{2}{c}{$144.3 \mathrm{~kW}$} \\
\cline { 3 - 8 } & & Operation & Simulation & Operation & Simulation & Operation & Simulation \\
\hline$\vartheta_{\text {SOFC }}$ & ${ }^{\circ} \mathrm{C}$ & 991 & $991^{*}$ & 981 & $981^{*}$ & 968 & $968^{*}$ \\
$\dot{m}_{F G}$ & $\mathrm{~kg} / \mathrm{h}$ & 19.9 & 19.68 & 22.24 & 21.557 & 26.00 & 25.260 \\
$U_{\text {cell }}$ & $\mathrm{V}$ & 0.682 & 0.6955 & 0.661 & 0.6855 & 0.639 & 0.6626 \\
$i_{\text {cell }}$ & $\mathrm{A} / \mathrm{m}^{2}$ & $1798.9^{* *}$ & 1765.37 & $1999.3 * *$ & 1933.88 & $2350.7 * *$ & 2266.04 \\
\hline
\end{tabular}


Table 3. Comparison Between the Operating Data from [73] and the Results of the Simulation Using the Model of a Natural Gas-Powered SOFC Power Plant.

\begin{tabular}{|c|c|c|c|c|c|}
\hline \multirow{2}{*}{ Parameter } & \multirow{2}{*}{ Unit } & \multicolumn{2}{|c|}{$120.7 \mathrm{~kW}$} & \multicolumn{2}{|c|}{$267.5 \mathrm{~kW}$} \\
\hline & & Operation & Simulation & Operation & Simulation \\
\hline$n_{\text {cell }}$ & & 1152 & $1152 *$ & 1704 & $1704^{*}$ \\
\hline$p_{\text {SOFC }}$ & bar & 1.05 & $1.05 *$ & 3.5 & $3.5^{*}$ \\
\hline$\dot{m}_{\text {anode,in }}$ & $\mathrm{kg} / \mathrm{s}$ & 0.03578 & 0.036270 & 0.08232 & 0.079971 \\
\hline$\dot{m}_{\text {air }}$ & $\mathrm{kg} / \mathrm{s}$ & 0.35 & 0.3181 & 0.634 & 0.6956 \\
\hline$U_{\text {cell }}$ & $\mathrm{V}$ & 0.69 & 0.695 & 0.639 & 0.6976 \\
\hline$i_{\text {cell }}$ & $\mathrm{A} / \mathrm{m}^{2}$ & 1800 & 1807.6 & 3000 & 2697.4 \\
\hline$P_{e l, c e l l, D C}$ & W & 104.8 & 104.77 & 157.0 & 156.98 \\
\hline$\eta_{F U}^{\prime}$ & $\%$ & 69.0 & 69.10 & 69.0 & 69.12 \\
\hline$\eta_{A U}$ & $\%$ & 17.8 & 19.69 & 23.8 & 19.87 \\
\hline$\vartheta_{\text {anode, in }}$ & ${ }^{\circ} \mathrm{C}$ & $550 * *$ & 533.6 & $587 * *$ & 579.5 \\
\hline$\vartheta_{\text {cathode, in }}$ & ${ }^{\circ} \mathrm{C}$ & $831 * *$ & 819.5 & $775^{* *}$ & 820.0 \\
\hline$x_{\mathrm{H}_{2}, \text { anode,in }}$ & & $0.258 * *$ & 0.2702 & $0.226 * *$ & 0.2335 \\
\hline$x_{\mathrm{H}_{2} \mathrm{O} \text {,anode, in }}$ & & $0.284 * *$ & 0.2767 & $0.334 * *$ & 0.3039 \\
\hline$x_{\mathrm{CH}_{4}, \text { anode,in }}$ & & $0.11 * *$ & 0.1042 & $0.131 * *$ & 0.1170 \\
\hline$x_{C O, \text { anode, in }}$ & & $0.057 * *$ & 0.0557 & $0.057 * *$ & 0.0572 \\
\hline$x_{\mathrm{CO}_{2}, \text { anode,in }}$ & & $0.228 * *$ & 0.2311 & $0.241 * *$ & 0.2250 \\
\hline$x_{N_{2}, \text { anode, in }}$ & & $0.063 * *$ & 0.0621 & $0.011 * *$ & 0.0634 \\
\hline
\end{tabular}

The comparison between the operating data from [73] and the results of the simulation are listed in Table 3 . The data of the SOFC operated under atmospheric pressure are listed in the left column; these of the SOFC module as part of a hybrid power plant are on the right side. Deviating from Table 1, other values for the operating pressure p $_{\text {SOFC }}$ are taken as input for the simulation, and in the case of the hybrid power plant, a SOFC stack with a higher number of cells $n_{\text {cells }}$ is used.

Results of the simulation appropriate for the validation are the mass flows of supplied air $\dot{m}_{\text {air }}$ and the prereformed natural gas $\dot{m}_{\text {anode, in }}$ as well as the electrical parameters of the individual cells. In addition, fuel utilization $\eta_{F U}^{\prime}$ regarding the one-time flow through the anode, therefore without consideration of anode off-gas recycling and the air exchange efficiency $\eta_{A U}$ can be used. Only as a check for plausibility, values for temperature and composition of the pre-reformed natural gas and the values for the temperature of the preheated air stream are listed; they are taken from previous publications of Campanari [47], [74].

Good agreement between simulation and operation data can be observed in the case of a SOFC power plant operating at atmospheric pressure. Here, only deviations in the variables concerning the pre-reforming and the air path are noticeable. It is evident that a higher conversion level for the pre-reforming process is assumed in the model than in the actual operation. This becomes clear by looking at the gas condition at the inlet of the anode, where lower temperatures - caused by the higher reaction rates of the endothermic reactions taking place in the pre-reformer and lower concentrations of methane are present. A lower cooling demand of the SOFC is the reason for less required air mass flow and consequently for higher air utilization factors.

The same observations can be reported in the pressurized SOFC module. In addition, differences in the electrical parameters voltage and current density can be noticed whilst the values of DC power of the single cell are nearly identical. The reason for these differences cannot be explained, since the values of $\dot{m}_{\text {anode,in }}$ and $\eta^{\prime}{ }_{F U}$ are almost exactly reproduced by the model.

As a result, in terms of the SOFC stack, it can be diagnosed that a good agreement between the calculated values by using the model and operational results in literature can be seen. The comparison with design and simulation results is discussed elsewhere [2], wherein the same tendencies and accuracy can be determined.

\section{Parametric Study for a Target Application}

The aim of this section is to analyze the performance of SOFC stacks under the expected conditions in hybrid power plants using the created simulation model. For this purpose, suitable parametric studies were conducted. The boundary conditions used are summarized in Table 4. The selected values are similar to those of natural gas-powered SOFC power plants.

Table 4: Boundary Conditions for the Parametric Studies Using the SOFC Model.

\begin{tabular}{|c|c|c|c|}
\hline Boundary condition & & Value & Unit \\
\hline Electrical power density & & 1250 & $\mathrm{~W} / \mathrm{m}^{2}$ \\
\hline Operating temperature & & 1000 & ${ }^{\circ} \mathrm{C}$ \\
\hline Operating pressure & & 1 & bar \\
\hline $\begin{array}{l}\text { Temperature difference } \\
\text { SOFC solid to gas outlet }\end{array}$ & between & 90 & ${ }^{\circ} \mathrm{C}$ \\
\hline $\begin{array}{l}\text { Temperature difference } \\
\text { SOFC solid to gas inlet }\end{array}$ & between & 200 & ${ }^{\circ} \mathrm{C}$ \\
\hline Fuel utilization & & 0.85 & \\
\hline Heat losses & & 2 & $\%$ \\
\hline
\end{tabular}


Table 5. Gradual Adjustment of the Fuel Composition.

\begin{tabular}{ccccccccc}
\hline \multirow{2}{*}{ Mixture } & \multicolumn{7}{c}{ Composition in molar parts [mol-\%] } \\
\cline { 2 - 8 } & $\mathrm{H}_{2}$ & $\mathrm{CO}$ & $\mathrm{H}_{2} \mathrm{O}$ & $\mathrm{N}_{2}$ & $\mathrm{Ar}$ & $\mathrm{CO}_{2}$ & $\mathrm{O}_{2}$ & $\mathrm{CH}_{4}$ \\
\hline 1 & 89.00 & & 11.00 & & & & & \\
2 & 79.00 & 10.00 & 11.00 & & & & & \\
3 & 69.00 & 20.00 & 11.00 & & & & & \\
4 & 59.00 & 30.00 & 11.00 & & & & & \\
5 & 49.00 & 40.00 & 11.00 & & & & & \\
6 & 39.00 & 50.00 & 11.00 & & & & & \\
7 & 29.00 & 60.00 & 11.00 & & & & & \\
8 & 25.67 & 55.75 & 4.46 & 10.26 & 0.07 & 3.81 & 0.03 & 0.02 \\
9 & 22.84 & 49.60 & 15.00 & 9.13 & 0.06 & 3.39 & 0.03 & 0.02 \\
10 & 14.78 & 32.10 & 44.95 & 5.91 & 0.04 & 2.19 & 0.02 & 0.01 \\
\hline
\end{tabular}

\subsection{Fuel Gas Composition}

The fuel composition is one of the relevant parameters for the content developed in this work. It is varied over the range listed in Table 5.

Starting with the reference conditions of the composition (Mixture 1), the composition of coal gas is gradually approached. As a result, different fuel processing levels are simulated. This is achieved by reducing the hydrogen content while increasing the carbon monoxide content (Mixtures 2 to 7). By further minor adjustments, the composition of clean gas from a Prenflo coal-gasification of "Pittsburgh no. 8"-coal is achieved (Mixture 8). Mixture 9 represents the composition of clean coal gas, which is humidified to 15 vol.- $\%$ of water vapor content as it is practiced in the IGCC Puertollano [75]. Even more moist is the coal gas "Mixture 10", with a steam to carbon molar flow ratio of $S / C=1.4$. It is needed for comparison with literature figures by Leone et al. [76].

These mixtures go into the model shown in Figure 1 as an input stream. As a result of the simulation, the values listed in Table 6 for a single cell can be obtained, wherein $\eta_{\text {el,cell }}$ is the electrical efficiency, $U_{\text {cell }}$ is the voltage, $i_{\text {cell }}$ is the current density and $\lambda$ is the excess air ratio.

Table 6. SOFC Simulation Results for the Different Fuel Compositions According to Table 5.

\begin{tabular}{ccccc}
\hline \multirow{2}{*}{ Mixture } & $\eta_{\text {el, cell }}$ & $U_{\text {cell }}$ & $i_{\text {cell }}$ & $\lambda$ \\
\cline { 2 - 5 } & {$[-]$} & {$[\mathrm{V}]$} & {$\left[\mathrm{A} / \mathrm{m}^{2}\right]$} & {$[-]$} \\
\hline 1 & 0.5026 & 0.7410 & 1695.08 & 10.76 \\
2 & 0.4920 & 0.7391 & 1699.25 & 11.19 \\
3 & 0.4815 & 0.7370 & 1704.27 & 11.63 \\
4 & 0.4710 & 0.7343 & 1710.51 & 12.09 \\
5 & 0.4605 & 0.7308 & 1718.64 & 12.56 \\
6 & 0.4495 & 0.7260 & 1729.90 & 13.07 \\
7 & 0.4375 & 0.7190 & 1746.87 & 13.63 \\
8 & 0.4463 & 0.7344 & 1710.20 & 13.26 \\
9 & 0.4265 & 0.7018 & 1789.55 & 13.93 \\
10 & 0.3862 & 0.6355 & 1976.28 & 15.03 \\
\hline
\end{tabular}

The electrical efficiency is highest with Mixture 1, at approximately $50 \%$ due to the high hydrogen content. The excess air ratio is approximately twice as high as in operation with pre-reforming natural gas, which agrees very well with results of Van Herle et al. [20]. The higher excess air is caused by the absence of methane - unlike prereforming natural gas - and thus no heat sink is provided by an endothermic reaction in the reaction chamber and the cooling of the exothermic reaction is supplied only by the excess air.

The approximation of the fuel composition from the composition at reference conditions to that of coal gas results in lower voltages being produced with the same electrical power density and a higher current density. This is due to the increasing importance of the internally occurring water-gas shift reaction, see Eq. (8), to higher carbon monoxide levels. Cooling demand and excess air ratio increase. The electrical efficiency of the single cell drops significantly by $6.5 \%$ points from Mixture 1 to Mixture 7.

The reduction of the water content is the reason for the slight energy improvements of Mixture 7 to Mixture 8, which is clean coal gas with all major species. Conversely, the additional moistening from Mixture 8 to Mixture 9 has a negative impact on efficiency.

The simultaneous check for soot formation is negative for all the mixtures in Table 5 under the given process conditions.

The by Leone et al. [76] published voltage-current density characteristics of a tubular SOFC cell of the same design for operation with different fuel compositions, including of the Mixture 1 and Mixture 10, can be reproduced by the model in very good agreement with the assumed process conditions. The literature source lacks relevant information on the conditions of measurement, so that at this point, only a qualitatively good agreement can be noted. It is the same for the data published by Krumbeck et al. [7] from measurements of a planar SOFC design. The therein illustrated voltage-current density characteristic curve for a synthesis gas/steam mixture to simulate a coal gas of a brown coal gasification shows only a minimally poorer electrochemical performance when the voltagecurrent density characteristic curve represents a hydrogen/steam reference gas mixture. This trend is also shown in Tsujimoto et al. [9], Weber et al. [77] and Sasaki et al. [78]. These measurements were carried out using gas mixtures with different $\mathrm{H}_{2} / \mathrm{CO}$-ratios under various operating conditions, wherein Sasaki et al. and Tsujimoto et al. consider a tubular SOFC of the company "TOTO Ltd." and Weber et al. a planar SOFC. The electrical effects of greater moistening with water vapor, as done from Mixture 8 to Mixture 9, were also qualitatively and quantitatively confirmed by the voltage-current density characteristics of Sasaki et al. 


\subsection{Pressure and Temperature}

The pressure and the temperature at which the SOFC stack is operated are also important parameters, which have a direct impact not only on the performance of the fuel cell, but also on the operating performance and the design of components that are connected up- and downstream in the process chain.

The simulation results for electrical efficiency of single cells for operation with cleaned coal gas (Mixture 8 in Table 5) with a variation of the operating pressure at different operating temperatures are shown in Figure 2.

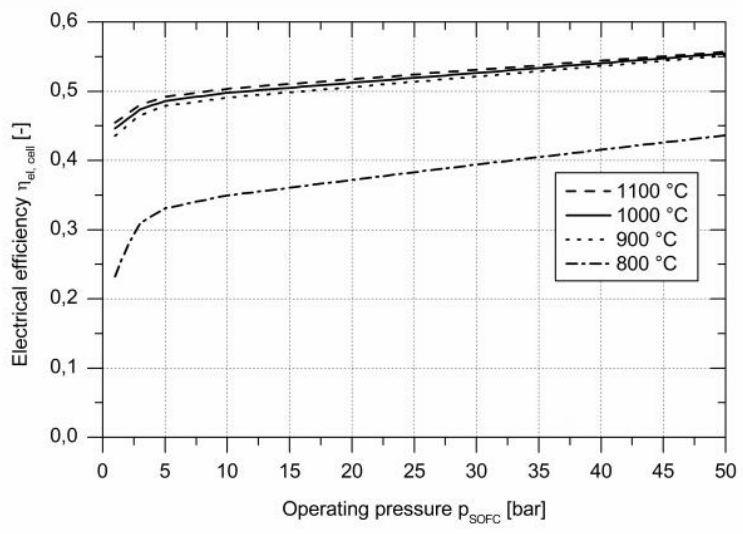

Figure 2. Electrical efficiency of a single cell as a function of the operating pressure for different operating temperatures when operating with coal gas.

With increasing operating pressure, the efficiency increases degressively, whereby the gradients below 5 bar are greater than at higher pressures. An almost linear dependence of the efficiency on the operating pressure is determined. In varying the operating temperature, it is particularly noticeable that only very small differences appear between the efficiency curves of $1100{ }^{\circ} \mathrm{C}, 1000^{\circ} \mathrm{C}$ and $900^{\circ} \mathrm{C}$, while the efficiency curve for $800^{\circ} \mathrm{C}$ is calculated significantly lower. The reason lies in the courses of the measured voltage-current density characteristics of [30]. At the chosen boundary conditions in Table 4, the operating range for the current density at the operating temperatures $1100{ }^{\circ} \mathrm{C}, 1000{ }^{\circ} \mathrm{C}$ and $900{ }^{\circ} \mathrm{C}$ is between 130 and $180 \mathrm{~mA} / \mathrm{cm}^{2}$. In this range, the voltagecurrent density curves at reference conditions in [30] also show only very small differences to each other. For the high operating temperatures, efficiencies are calculated for 1 bar at about $45 \%$, for 10 bar at about $50 \%$ and for 50 bar at about $55 \%$. At $800{ }^{\circ} \mathrm{C}$, the electrical efficiency for 1 bar is only $23 \%$, for 10 bar $35 \%$ and for 50 bar $45 \%$. Thus, the values for the efficiency at different operating temperatures approach each other with increasing pressure.

An important aspect when looking at different operating pressures and temperatures concerns soot formation. With increasing pressure and decreasing temperature, the tendency to form soot grows. For the considered coal gas, soot formation can thermodynamically be excluded at $1100{ }^{\circ} \mathrm{C}$ only below 29 bar. At $1000{ }^{\circ} \mathrm{C}$, the limit already has sunk to 8 bar. At $900{ }^{\circ} \mathrm{C}$, however, the SOFC can be operated safely below 2 bar; at $800^{\circ} \mathrm{C}$ even at 1 bar.

For this reason, the results in Figure 2 are compared with simulation results, which were obtained with humidified coal gas (Mixture 9 in Table 5). For this, the curves of the electrical efficiencies of single cells shown in
Figure 3 are calculated over the operating pressure at different operating temperatures.

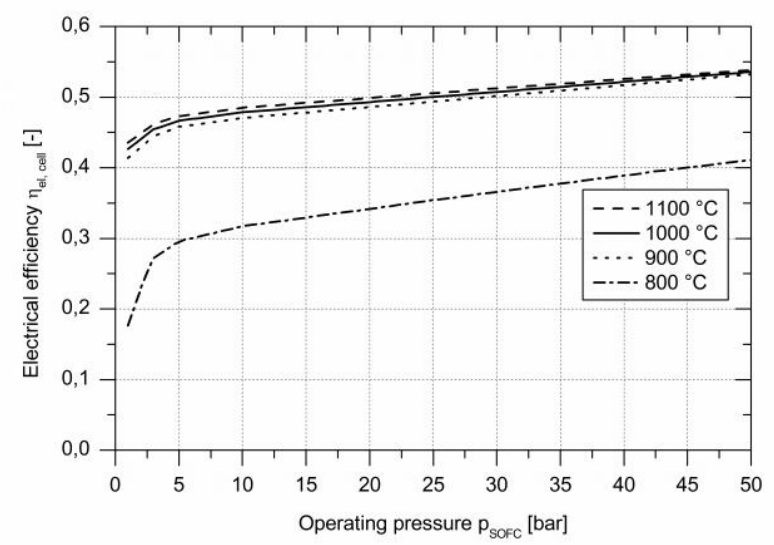

Figure 3. Electrical efficiency of a single cell as a function of the operating pressure for different operating temperatures when operating with humidified coal gas.

At pressures below 3 bar, the calculated efficiency at $800{ }^{\circ} \mathrm{C}$ is between 4 and $5.5 \%$-points lower than without saturation. At higher pressures, the difference decreases to $2.5 \%$-points. For the three higher temperatures, the efficiency over the entire considered pressure range is around $2 \%$-points worse.

In addition to the moderately lower efficiency, due to the higher humidity, the SOFC can be operated over a much larger pressure range without risk of soot formation. At $1100{ }^{\circ} \mathrm{C}$, operation is safe over the whole pressure range at $1000{ }^{\circ} \mathrm{C}$ below $31 \mathrm{bar}$ and at $900{ }^{\circ} \mathrm{C}$ below 6.5 bar. At $800{ }^{\circ} \mathrm{C}$, the SOFC can be operated at atmospheric pressure without potential risk.

\subsection{Fuel Utilization and Electrical Power Density}

The fuel utilization and the electrical power density are other important design parameters of fuel cells with significant impact on the performance and the design of upand downstream components.

For various electric power densities, the fuel utilization is varied in the simulation of the SOFC operation with cleaned coal gas (Mixture 8 in Table 5). As a simulation result, both the electrical efficiency according to Eq. (2) and the net electrical efficiency according to Eq. (3) are shown above the electric conversion efficiency for different power densities in Figure 4. In addition to the value specified in Table 4 default value of $1250 \mathrm{~W} / \mathrm{m}^{2}$, values for the electrical power density of $33 \%, 50 \%, 66 \%, 150 \%$ and $200 \%$ of this value are selected.

In general, with increasing fuel utilization, a strong increase in electrical efficiency and a less strong decrease in net electrical efficiency can be observed. Over the entire range of fuel utilization, it can be determined that with increasing power density, both efficiencies progressively decrease and that the three lowest of the considered power densities attain hardly distinguishable results. Lowering the power density is therefore only effective below a certain value. The economic component of the physical size for achieving a given power is not considered here. 


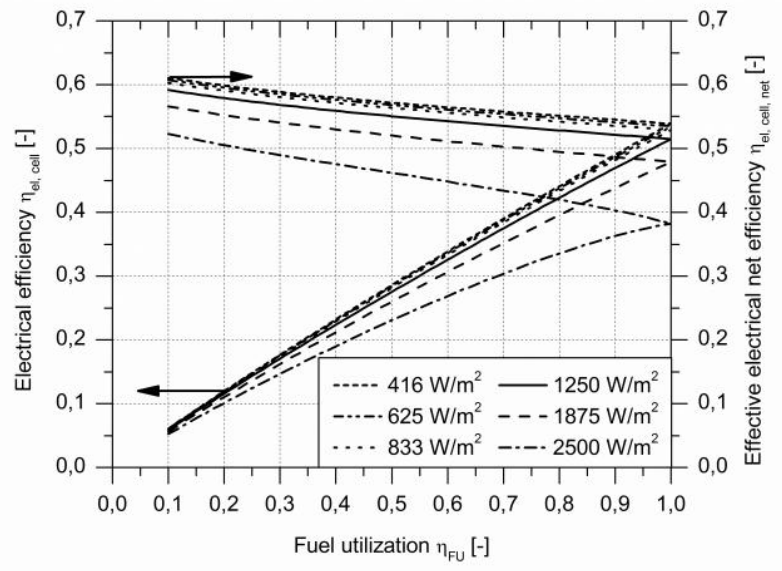

Figure 4. Electrical efficiencies of a single cell as a function of fuel utilization for different electrical power densities when operating with coal gas.

It has to be noted that the curve progression of electrical efficiency to fuel utilization shows results for different electrical power densities that are very close together with very low fuel utilization; at $\eta_{F U}=0.1$, for example, all efficiencies are between 5 and $6 \%$. With increasing fuel utilization, the differences are more significant; at $\eta_{F U}=0.5$, the efficiency at the maximum power density is $23 \%$, at the lowest power density $29 \%$ and at $\eta_{F U}=0.85$, the range is between $35 \%$ and $47 \%$.

Since the net efficiency is calculated by dividing the efficiency by fuel utilization, the individual results and the range of results that occur are therefore ten times as large at $\eta_{F U}=0.1$ and twice at $\eta_{F U}=0.5$. The net electrical efficiency at $\eta_{F U}=0.85$ is between $41 \%$ at $2500 \mathrm{~W} / \mathrm{m}^{2}$ and $55 \%$ at $416 \mathrm{~W} / \mathrm{m}^{2}$.

For comparison, the same variation of the fuel utilization for the various electrical power densities is calculated for humidified coal gas (Mixture 9 in Table 5). The results are shown in Figure 5.

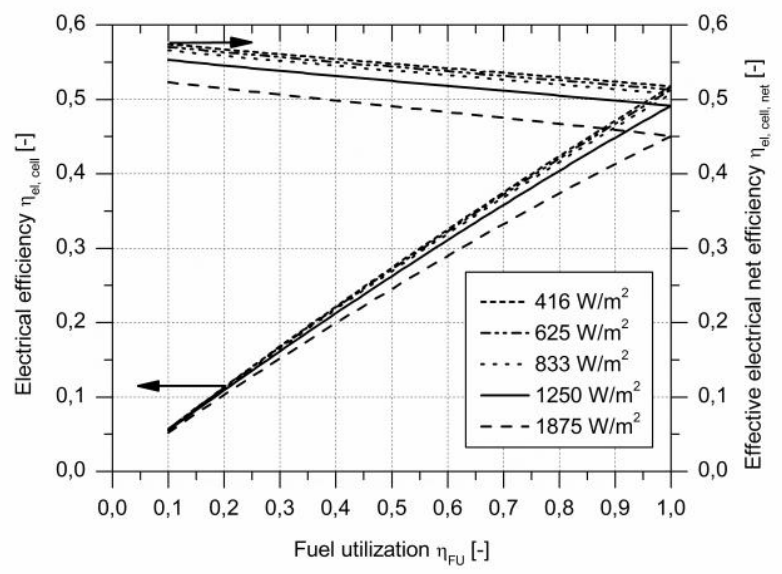

Figure 5. Electrical efficiencies of a single cell as a function of fuel utilization for different electrical power densities operating with humidified coal gas.

The observations described above apply here substantially as well. The differences are due to the higher water content in the coal gas. The absolute values for the efficiency are slightly lower, and these differences are increased when considering conversion efficiencies. At $\eta_{F U}=0.1$, the electrical efficiencies of humidified coal gas as compared to unhumidified coal gas are only $0.4 \%$-points lower; at $\eta_{F U}=0.85$ the difference is already $2 \%$-points.

Comparable measurements or simulations are not available in literature. At most, the results of the simulations of Panopoulos et al. [79] permit a conditional comparability; here, a system of biomass gasifier coupled with a tubular SOFC stack from Siemens was studied. Taking into account the different boundary conditions and fuel compositions, the source shows a qualitatively similar influence of $\eta_{F U}$ on the electric power and thus the electrical efficiency.

\subsection{Characteristic Diagrams}

The diagrams discussed here are obtained from the simulation and results of extensive parallel variations of the parameters operating pressure $p_{\mathrm{SOFC}}$ and fuel utilization $\eta_{F U}$, which are the main manipulated variables on SOFC hybrid power plants. With the help of the diagrams, the electric and energetic performance of the SOFC over a wide range of $p_{\text {SOFC }}$ and $\eta_{F U}$ are described by isolines for discrete values of the electrical efficiency of the single cell $\eta_{e l, c e l l}$ and the electrical voltage of the single cell $U_{\text {cell }}$. Furthermore, since the electric power density for the calculation is assumed to be constant, corresponding isolines for the current density can be calculated for the $U_{\text {cell }}$ isolines, wherein the resulting profiles of the isolines are identical to those of the corresponding voltage. Moreover, from the values of $\eta_{e l, c e l l}$ and $\eta_{F U}$, isolines for net electrical efficiencies of the single cell $\eta_{\text {el, cell,net }}$ can be calculated. The type of plotting allows for a clear demarcation of operational areas with potential risk for degradation by soot from those in which soot formation is thermodynamically impossible.

Figure 6 is the diagram for use with cleaned coal gas (Mixture 8 in Table 5). The limit for soot formation lies at 7.9 bar; below this pressure, a soot formation is thermodynamically excluded. As already discussed, this range can be enlarged by increasing the steam-to-carbon molar flow ratio $S / C$. Accordingly, it is convenient also to look at a characteristic diagram for operation with humidified coal gas (Mixture 9), see Figure 7. The humidification to 15 vol.- $\%$ water vapor content results in an increase in the limit for soot formation to 31.2 bar. However, the wetting caused lower values for the energy and electrical parameters.

Generally, it can be stated that at $\eta_{F U}=$ const with increasing operating pressure $p_{\text {SOFC }}$, higher values for the electrical efficiency of the single cell $\eta_{\text {el,cell }}$ can be achieved, where the values for the voltage of the single cell $U_{\text {cell }}$ increase. With increasing $\eta_{F U}$, the influence of $p_{\mathrm{SOFC}}$ on $\eta_{\text {el,cell }}$ is greater. With decreasing $\eta_{F U}$ and $p_{\text {SOFC }}=$ const, the calculated values for the voltages $U_{\text {cell }}$ are greater. The reason is the higher existing hydrogen partial pressure as a result of the oversupply of fuel.

In the following, specific relevant operating points are discussed on the basis of the diagrams, wherein the values for the humidified coal gas are in brackets:

- When $\eta_{F U}=0.97$ and $p_{\mathrm{SOFC}}=1$ bar $(2.3 \mathrm{bar})$, an efficiency of $\eta_{\text {el,cell }}=0.5$ at a voltage range of $0.7 \mathrm{~V}<U_{\text {cell }}<0.75 \mathrm{~V}$ will be achieved and at $p_{\text {SOFC }}=35$ bar $\left(47.5\right.$ bar), an efficiency of $\eta_{\text {el,cell }}=0.6$, whereby the voltage is in the range of $0.85 \mathrm{~V}<U_{\text {cell }}<0.9 \mathrm{~V}$. 
- When $\eta_{F U}=0.85$, an efficiency of $\eta_{\text {el,cell }}=0.5$ is attainable only at operating pressures of 11-12 bar (2425 bar), whereas the voltage is adjusted in the range of $0.8 \mathrm{~V}<U_{\text {cell }}<0.85 \mathrm{~V}$.

- The impact of the pressure is significantly lower at fuel utilization $\eta_{F U}=0.5$, so that an efficiency of $\eta_{\text {el,cell }} \approx 0.3$ will be achieved over a wide pressure range of 5 bar $\leq p_{\mathrm{SOFC}} \leq 7.5$ bar $\left(17.5 \mathrm{bar} \leq p_{\mathrm{SOFC}} \leq 20 \mathrm{bar}\right)$. The voltage $U_{\text {cell }}$ is between $0.8 \mathrm{~V}$ and $0.85 \mathrm{~V}$. At this fuel utilization, a voltage of $0.9 \mathrm{~V}$ will only be obtained with $p_{\mathrm{SOFC}}=30$ bar $(47.5 \mathrm{bar})$. The efficiency is then greater than 0.3 .

- At $p_{\mathrm{SOFC}}=15 \mathrm{bar}$, a voltage of $U_{\text {cell }}=0.85 \mathrm{~V}$ is achievable at a fuel utilization of $\eta_{F U}=0.65(0.29)$ and an efficiency of $\eta_{\text {el,cell }}=0.4 \quad(0.17)$, while for $U_{\text {cell }}=0.9 \mathrm{~V}$ a substantially higher fuel excess with very low values of $\eta_{F U}=0.225$ and $\eta_{\text {el, cell }}=0.14$ is required. In the case of humidified coal gas, such a high voltage is not reachable at these conditions.

It should again be noted that the model used is based on the assumption that the simulation of a single cell can be used representatively to calculate the performance of a whole stack. Thus, the described diagrams are equivalent for stacks.

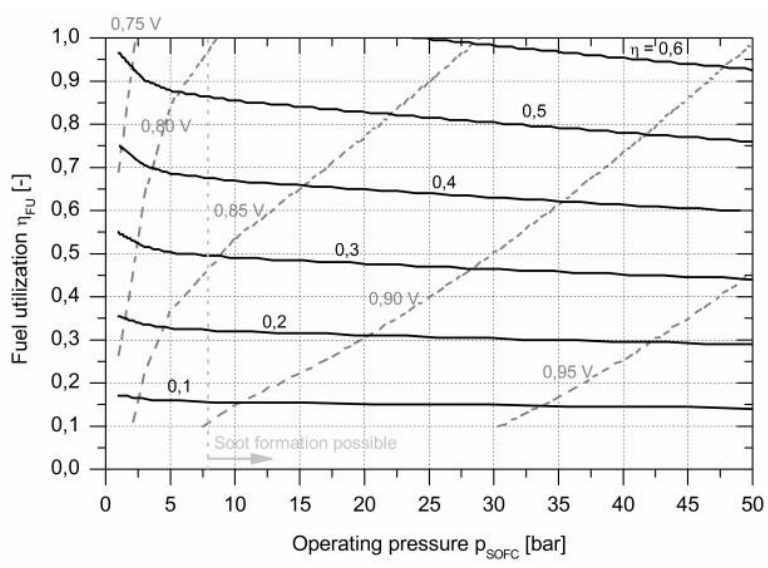

Figure 6. Diagram for operation with coal gas.

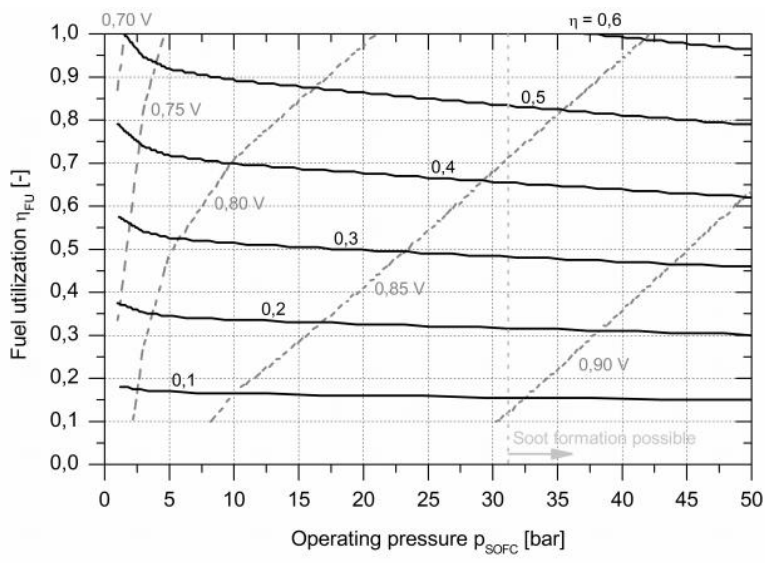

Figure 7. Diagram for operation with humidified coal gas.

\section{Summary and Conclusions}

In order to simulate complex hybrid power plants, simplified process models are needed. In this article, a model for a tubular solid oxide fuel cell (SOFC) based on a semi-empirical approach is developed. It is a steady state zero-dimensional model, utilizing various built-in components of the applied process simulation software. The semi-empirical approach uses a voltage-current characteristic curve measured at precisely defined conditions as a reference and the semi-empirical correlations based on Nernst voltage in case of deviating operating conditions with regard to operating temperature and pressure as well as the compositions of the fuel gas and the oxidizing agent. The elaborated model is compared with operating data of demonstration plants published in literature. For all parameters, the calculated values of the model reproduce the operating data fairly precisely. Therefore, the elaborated model for the tubular SOFC is validated.

Extensive parametric study was performed. The results of these studies regarding variations of the fuel gas composition, operating pressure and temperature as well as fuel utilization and electrical power density are presented. Additionally, characteristic diagrams are drawn, which were obtained by variation of the operating pressure and the fuel utilization. With the help of these diagrams, the electric and energetic performance of the SOFC over a wide range of these parameters can be described. Due to these results, it can be concluded that the created model of the tubular SOFC is qualified for implementation in system models such as those of SOFC hybrid power plants with integrated coal gasification.

\section{Appendix: Electrochemistry Algorithm}

In this section, the calculation algorithm for electrochemistry of a SOFC stack is listed.

1. Specification of $A_{\text {stack }}, P_{\text {el,stack }}$ und $\eta_{F U}$.

2. Calculation of the required number of cells $n_{\text {cells }}$, which is not rounded to integer values:

$n_{\text {cells }}=\frac{A_{\text {stack }}}{A_{\text {cell }}}$

with $A_{\text {cell }}=0.0834 \mathrm{~m}^{2}=$ active area of a cell.

3. Calculation of the electrical power of a cell $P_{\text {el,cell }}$ :

$P_{\text {el,cell }}=\frac{P_{\text {el,stack }}}{n_{\text {cells }}}$

4. Calculating the arithmetic average values of the partial pressures of $\mathrm{H}_{2}, \mathrm{H}_{2} \mathrm{O}$ und $\mathrm{O}_{2}$ at in- and outlet of the stack:

$$
\begin{aligned}
& \overline{p_{\mathrm{H}_{2}}}=\frac{p_{\mathrm{H}_{2}, \text { anode }, \text { in }}+p_{\mathrm{H}_{2}, \text { anode,out }}}{2} \\
& \overline{p_{\mathrm{H}_{2} \mathrm{O}}}=\frac{p_{\mathrm{H}_{2} \mathrm{O}, \text { anode, } \text { in }+p_{\mathrm{H}_{2} \mathrm{O}, \text { anode,out }}}}{2} \\
& \overline{p_{\mathrm{O}_{2}}}=\frac{p_{\mathrm{O}_{2}, \text { cathode, in }}+p_{\mathrm{O}_{2}, \text { cathode }, \text { out }}}{2}
\end{aligned}
$$

5. Setting a starting value for the current density $i$.

6. Calculations of an initial value for the current voltage $U$ :

As opposed to the formula used within the iteration for the calculation of $U$, the calculation of the initial value is only approximate. For this purpose, the equation published by Campanari [47] for the current voltage is used.

$U=U_{\text {ref }}+\Delta U_{T}+\Delta U_{p}+\Delta U_{\text {anode }}+\Delta U_{\text {cathode }}$ 
Specifically, this consists of a voltage component at reference conditions $U_{r e f}$, and is determined as a function of the previously specified current density of a voltage-current density curve, and the sum of the potential differences in deviating from the terms of reference conditions regarding operating temperature $\Delta U_{T}$, operating pressure $\Delta U_{p}$, fuel gas composition $\Delta U_{\text {anode }}$ and oxidant composition $\Delta U_{\text {cathode. }}$ These semiempirical correlations similar to the Nernst equation that can have both positive and negative values depending on the boundary conditions, are given in the literature source.

7. Calculation of the current value of current strength of a cell $I_{\text {cell }}$ :

$$
I_{\text {cell }}=\frac{P_{e l, \text { cell }}}{U}
$$

8. Calculation of the need for an equivalent hydrogen molar stream taking into account the given fuel utilization with the help of Faraday's Law:

$\dot{N}_{H_{2}, r e q}=\frac{I_{\text {cell }}}{n F \eta_{F U}}$

with $n=2=$ Number of electrons exchanged in the reaction and

$F=96485.3 \mathrm{C} / \mathrm{mol}=$ Faraday constant

9. Calculation of the resulting clean gas molar flow

$\dot{N}_{\text {cleangas,cell }}$ per cell:

$\dot{N}_{\text {cleangas,cell }}=\frac{\dot{N}_{H_{2}, \text { req }}}{x_{\mathrm{H}_{2}, \text { cleangas }}+x_{\mathrm{CO}, \text { cleangas }}}$

with

$$
\begin{aligned}
x_{H_{2}, \text { cleangas }}= & \text { Mole fraction of hydrogen } \\
& \text { in clean gas [-] } \\
x_{C O, \text { cleangas }}= & \text { Mole fraction of carbon } \\
& \text { monoxide in clean gas [-] }
\end{aligned}
$$

10. Calculation the current density $i$ :

$$
i=\frac{I_{\text {cell }}}{A_{\text {cell }}}
$$

11. Calculation of the reference voltage $U_{r e f}$ at the calculated current density by equation A.11 derived by an approximation of the voltage-to-current density characteristic curve at the operating temperature of $1000{ }^{\circ} \mathrm{C}$ from [30] with a second-degree polynomial.

$$
\frac{U_{\text {ref }}}{\mathrm{V}}=-8.387 \cdot 10^{-9}\left(\frac{i}{\mathrm{~A} / \mathrm{m}^{2}}\right)^{2}-8.903 \cdot 10^{-6}\left(\frac{i}{\mathrm{~A} / \mathrm{m}^{2}}\right)+0.7796
$$

12. Same as step 4.

13. Calculations of the current voltage $U$ : Analogous to equation A.6 for $U$ published by Campanari [47], the potential differences $\Delta U_{\text {anode, }}$, $\Delta U_{\text {cathode }}, \Delta U_{p}$ und $\Delta U_{T}$ are added to reference voltage $U_{\text {ref }}$ determined in step 11 . In the case of $\Delta U_{\text {anode }}$ und $\Delta U_{\text {cathode, }}$, these are compensation terms, which describe the change of the Nernst voltage at operating conditions that differ with respect to the measurement conditions during recording of the reference curve. These must be included, so that for $\Delta U_{\text {anode }}$, equation $\mathrm{A} .12$ and for $\Delta U_{\text {cathode, }} \quad$ equation $\quad$ A.13 results.
$\Delta U_{\text {anode }}=\frac{R T}{2 F} \ln \left(\frac{\overline{p_{H_{2}}}}{\overline{{\overline{H_{2}}} \mathrm{O}}}\right)-\frac{R T_{\text {ref }}}{2 F} \ln \left(\frac{\overline{p_{\mathrm{H}_{2}}}}{\overline{\bar{p}_{\mathrm{H}_{2} \mathrm{O}}}}\right)_{\text {ref }}$

with $\mathrm{R}=8.31447 \mathrm{~J} /(\mathrm{mol} \cdot \mathrm{K})$ universal gas constant $\mathrm{T}=$ fuel cell temperature $[\mathrm{K}]$

$\Delta U_{\text {cathode }}=\frac{R T}{4 F} \ln \left(\overline{p_{O_{2}}}\right)-\frac{R T_{r e f}}{4 F} \ln \left(\overline{p_{O_{2}}}\right)_{\text {ref }}$

In the case of $\Delta U_{p}$ and $\Delta U_{T}$, the measured voltagecurrent density characteristics of [30] are used. For this purpose, the relationship between voltage and current density is approximated by second order polynomials using the measured points. Operating points lying between the curves are linearly interpolated. Operating points lying above or below the curves are extrapolated with a nearest interpolation equation. Since the equations A.12 und A.13 are pressure and temperature dependent, the A.14 and A.15 corresponding correction terms are included to prevent double counting in the equations. In equation A.14 for $\Delta U_{p}$, the pressuredependent voltage-to-current density characteristics of [30] are incorporated. These are measured at a lower air utilization $\eta_{A U}$ than in the measurement of voltage-tocurrent density characteristics under reference conditions.

$\Delta U_{p}=\Delta U_{p}^{*}+\Delta U_{\text {cathode }}\left(p, \eta_{A U}=0.167\right)$

with

$\Delta U_{p}^{*}=\left\{\begin{array}{cc}\frac{U_{3 \mathrm{bar}}-U_{1 \mathrm{bar}}}{3 \mathrm{bar}-1 \mathrm{bar}}(p-1 \mathrm{bar}) & : 1 \mathrm{bar}<p \leq 3 \mathrm{bar} \\ U_{3 \mathrm{bar}}+\frac{U_{5 \mathrm{bar}}-U_{3 \mathrm{bar}}}{5 \mathrm{bar}-3 \mathrm{bar}}(p-3 \mathrm{bar})-U_{1 \mathrm{bar}} & : 3 \mathrm{bar}<p \leq 5 \mathrm{bar} \\ U_{5 \mathrm{bar}}+\frac{U_{1 \mathrm{bar}}-U_{5 \mathrm{bar}}}{10 \mathrm{bar}-5 \mathrm{bar}}(p-5 \mathrm{bar})-U_{1 \mathrm{bar}} & : 5 \mathrm{bar}<p \leq 10 \mathrm{bar} \\ U_{10 \mathrm{bar}}+\frac{U_{15 \mathrm{bar}}-U_{10 \mathrm{bar}}}{15 \mathrm{bar}-10 \mathrm{bar}}(p-10 \mathrm{bar})-U_{1 \mathrm{bar}} & : p>10 \mathrm{bar}\end{array}\right.$

with

$\frac{U_{1 \text { bar }}}{\mathrm{V}}=-6.164 \cdot 10^{-9}\left(\frac{i}{\mathrm{~A} / \mathrm{m}^{2}}\right)^{2}-3.161 \cdot 10^{-5}\left(\frac{i}{\mathrm{~A} / \mathrm{m}^{2}}\right)+0.8110$

$\frac{U_{3 \mathrm{bar}}}{\mathrm{V}}=-2.820 \cdot 10^{-9}\left(\frac{i}{\mathrm{~A} / \mathrm{m}^{2}}\right)^{2}-3.989 \cdot 10^{-5}\left(\frac{i}{\mathrm{~A} / \mathrm{m}^{2}}\right)+0.8572$

$\frac{U_{5 \mathrm{bar}}}{\mathrm{V}}=-3.113 \cdot 10^{-9}\left(\frac{i}{\mathrm{~A} / \mathrm{m}^{2}}\right)^{2}-3.892 \cdot 10^{-5}\left(\frac{i}{\mathrm{~A} / \mathrm{m}^{2}}\right)+0.8751$

$\frac{U_{10 \mathrm{bar}}}{\mathrm{V}}=-2.082 \cdot 10^{-9}\left(\frac{i}{\mathrm{~A} / \mathrm{m}^{2}}\right)^{2}-4.295 \cdot 10^{-5}\left(\frac{i}{\mathrm{~A} / \mathrm{m}^{2}}\right)+0.8972$

$\frac{U_{15} \mathrm{bar}}{\mathrm{V}}=-2.737 \cdot 10^{-9}\left(\frac{i}{\mathrm{~A} / \mathrm{m}^{2}}\right)^{2}-4.034 \cdot 10^{-5}\left(\frac{i}{\mathrm{~A} / \mathrm{m}^{2}}\right)+0.9059$

$\Delta U_{\text {cathode }}\left(p, \eta_{A U}=0.167\right)=\frac{R T_{\text {ref }}}{4 F}\left[\ln \left(\overline{p_{O_{2}}}\right)_{\text {ref }}-\ln \left(\left(\overline{x_{O_{2}}}\right)_{\eta_{A U}=0.167} p\right)\right]$

$p=$ operating pressure $[\mathrm{bar}]$

$\left(\overline{x_{O_{2}}}\right)_{\eta_{A U}=0.167}=0.1956=$ arithmetic mean of the oxygen mole fraction at the inlet and outlet of the stack

$\Delta U_{T}=\Delta U_{T}^{*}+\Delta U_{\text {anode }}(T)+\Delta U_{\text {cathode }}(T)$

with

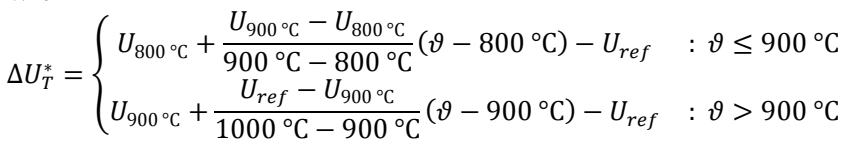

with

$\frac{U_{800}{ }^{\circ} \mathrm{C}}{\mathrm{V}}=-2.204 \cdot 10^{-8}\left(\frac{i}{\mathrm{~A} / \mathrm{m}^{2}}\right)^{2}-2.314 \cdot 10^{-4}\left(\frac{i}{\mathrm{~A} / \mathrm{m}^{2}}\right)+0.9039$ 
$\frac{U_{900}{ }^{\circ} \mathrm{C}}{\mathrm{V}}=-2.727 \cdot 10^{-9}\left(\frac{i}{\mathrm{~A} / \mathrm{m}^{2}}\right)^{2}-7.963 \cdot 10^{-5}\left(\frac{i}{\mathrm{~A} / \mathrm{m}^{2}}\right)+0.8675$

$\Delta U_{\text {anode }}(T)=\frac{R}{2 F} \ln \left(\frac{\overline{p_{H_{2}}}}{\overline{{\overline{H_{2}}}_{2} \mathrm{O}}}\right)_{\text {ref }}\left(T_{\text {ref }}-T\right)$

$\Delta U_{\text {cathode }}(T)=\frac{R}{4 F} \ln \left(\overline{p_{O_{2}}}\right)_{\text {ref }}\left(T_{\text {ref }}-T\right)$

14. Calculation of the current strength of the stack $I_{\text {stack}}$ :

$$
I_{\text {stack }}=\frac{P_{\text {el,stack }}}{U}
$$

15. Calculation of the clean gas molar flow

$\dot{N}_{\text {cleangas,stack }}$ for the stack:

$$
\dot{N}_{\text {cleangas,stack }}=\dot{N}_{\text {cleangas,cell }} \cdot n_{\text {cells }}
$$

16. Determining whether the calculation has converged:

$$
U \cdot I_{\text {stack }}=\left(1 \pm 10^{-6}\right) P_{\text {el,stack }} \text { ? }
$$

Yes: Go to step 17 !

No: Back to step 7!

17. Calculation of the actual electric power of the stack:

$P_{\text {el,stack }}=U \cdot I_{\text {stack }}$

\section{Nomenclature}

A Area $\left[\mathrm{m}^{2}\right]$

$\Delta^{R} G \quad$ enthalpy of reaction $[\mathrm{J} / \mathrm{mol}]$

$e_{\text {loss }} \quad$ Loss factor

$F \quad$ Faraday constant $=96485.3 \mathrm{C} / \mathrm{mol}$

$H_{u} \quad$ Net calorific value $[\mathrm{kJ} / \mathrm{kg}]$

$\dot{m} \quad$ Mass flow $[\mathrm{kg} / \mathrm{s}]$

$\dot{N} \quad$ Molar flow [mol/s]

$n$ number of electrons exchanged during reaction

$P \quad$ Power $[\mathrm{kW}]$

$p \quad$ (Partial) pressure $[\mathrm{Pa}]$

$p^{0} \quad$ Reference pressure (at standard conditions) $[\mathrm{Pa}]$

$\bar{p} \quad$ Average (partial) pressure $[\mathrm{Pa}]$

$\dot{Q} \quad$ Heat flow $[\mathrm{kW}]$

$R \quad$ Universal gas constant $=8.31447 \mathrm{~J} /(\mathrm{mol} \mathrm{K})$

$S / C \quad$ Steam to carbon molar flow ratio

$T \quad$ Temperature [K]

$U \quad$ Voltage [V]

$x \quad$ Molar part

$\eta \quad$ Efficiency

$\eta_{A U} \quad$ Air exchange efficiency

$\eta_{F U} \quad$ Fuel utilization

$\vartheta \quad$ Temperature $\left[{ }^{\circ} \mathrm{C}\right]$

$\lambda \quad$ Excess air ratio

$v \quad$ Stoichiometric coefficient

Indices:

air air

anode anode

cathode cathode

cell cell

cleangas cleangas

el electrical

$F G \quad$ fuel gas

$i \quad$ component $\mathrm{i}$

$\begin{array}{ll}\text { in } & \text { inlet } \\ N & \text { Nernst } \\ \text { net } & \text { net } \\ \text { loss } & \text { loss } \\ \text { out } & \text { outlet } \\ p & \text { pressure } \\ \text { ref } & \text { reference } \\ \text { req } & \text { required } \\ \text { stack } & \text { stack } \\ \text { SOFC } & \text { SOFC } \\ \text { T } & \text { temperature } \\ \text { ut } & \text { utilized }\end{array}$

Acronyms:

IGCC Integrated gasification combined cycle

IGFC Integrated gasification fuel cell

Prenflo Pressurised entrained flow

\section{References}

[1] M. Krüger, "Process Development for Integrated Coal Gasification SOFC Hybrid Power Plants" in Proceedings of the 2nd International Conference on Energy Process Engineering, Frankfurt am Main, 2011.

[2] M. Krüger, Verfahrensentwicklung für SOFCHybridkraftwerke mit integrierter Kohlevergasung, München: Dr. Hut, 2013.

[3] R. K. Shah, "Introduction to Fuel Cells" in S. Basu (Ed.), Recent Trends in Fuel Cell Science and Technology, Berlin: Springer, 2007, pp. 1-9.

[4] R. Bove, "Solid Oxide Fuel Cells: Principles, Designs and State-of-the-Art in Industries", in S. Basu (Ed.), Recent Trends in Fuel Cell Science and Technology, Berlin: Springer, 2007, pp. 267-285.

[5] J. Larminie, A. Dicks, Fuel Cell Systems Explained, $2^{\text {nd }}$ Ed., Chichester: Wiley, 2003.

[6] S. S. C. Chuang, Carbon-based Fuel Cell, Technical Report, DE-PS26-03NT41803, Pittsburgh: U.S. Department of Energy (DOE), 2006.

[7] M. Krumbeck, T. Kloidt, H. Landes, R. Schamm, H.-P. Schiffer, "Einsatz von Hochtemperatur-Brennstoffzellen (SOFC) mit Braunkohlegas" in Proceedings of the $10^{\text {th }}$ $D V V$ / $1^{\text {st }}$ SVV-Kolloquium "HochtemperaturBrennstoffzellen und katalytische Verbrennung", Zürich, 1996.

[8] J. P. Trembly, A. I. Marquez, T. R. Ohrn, D. J. Bayless, Effects of coal syngas and $\mathrm{H}_{2} \mathrm{~S}$ on the performance of solid oxide fuel cells: Single-cell tests, J. Power Sources, doi:10.1016/j.jpowsour.2005.09.055

[9] K. Tsujimoto, Y. Uchida, K. Sasaki, K. Susuki, Y.-i. Hori, Y. Teraoka, K. Eguchi, A. Ueno, K.-i. Hiwatashi, M. Aizawa, "Power Generation Characteristics of Solid Oxide Fuel Cells Operated with Simulated Coal Gas" in Proceedings of the 5th European Solid Oxide Fuel Cell Forum, Luzern, 2002.

[10] P. V. Aravind, J. P. Ouweltjes, N. Woudstra, B. Rietveld, "SOFC Performance with Biomass-Derived Gas" in Proceedings of the 6th European Solid Oxide Fuel Cell Forum, Luzern, 2004. 
[11] M. Heddrich, M. Jahn, F. Marschallek, R. Näke, "Entwicklung und Aufbau eines Brennstoffzellensystems für Biogas" in Proceedings of the 6th Fachtagung Brennstoffzelle, Braunschweig, 2008.

[12] G. Schiller, Untersuchung von Rohgas aus der Biomassevergasung für den Einsatz in oxidkeramischen Festelektrolyt-Brennstoffzellen (SOFC), Technical Report, DLR (German Aerospace Centre), Institute of Technical Thermodynamics, Stuttgart, 2007.

[13] J. Van Herle, F. Maréchal, S. Leuenberger, D. Favrat, Energy balance model of a SOFC cogenerator operated with biogas, J. Power Sources, doi:10.1016/S03787753(03)00103-4.

[14] J. Pusz, R. Bove, N. M. Sammes, "Landfill Gas Energy Recovery Based on Micro-Tubular Solid Oxide Fuel Cells" in Proceedings of the 9th International Symposium on Solid Oxide Fuel Cells (SOFC-IX), Quebec, 2005.

[15] J. Staniforth, K. Kendall, Cannock landfill gas powering a small tubular solid oxide fuel cell - a case study, J. Power Sources, doi:10.1016/S03787753(99)00417-6.

[16] S. F. Au, L. Blum, A. Dengel, B. Groß, L. H. J. de Haart, K. Kimmerle, M. Wolf, Utilization of mine gas with a high-temperature SOFC fuel cell, J. Power Sources, doi:10.1016/j.jpowsour.2004.12.073.

[17] A. Blum, Ludger und Dengel, H. K. Dörr, B. Groß, L. G. J. B. de Haart, K. Kimmerle, "Betrieb einer Hochtemperaturbrennstoffzelle mit Grubengas" in Proceedings of the 5th Fachtagung Brennstoffzelle, Hamburg, 2005.

[18] L. Blum, Pilotbetrieb einer Hochtemperaturbrennstoffzelle (SOFC) mit Grubengas, Technical Report, Saarbrücken: Evonik New Energies GmbH, 2007.

[19] M. Blesl, M. Ohl, U. Fahl, "Systemintegration von Brennstoffzellen in Kläranlagen. Eine energetische, ökonomische und ökologische Bewertung”, BWK: Das Energie-Fachmagazin 58, 51-56, 2006.

[20] J. Van Herle, F. Maréchal, S. Leuenberger, Y. Membrez, O. Bucheli, D. Favrat, Process flow model of solid oxide fuel cell system supplied with sewage biogas, J. Power Sources, doi:10.1016/j.jpowsour.2004.01.013.

[21] H. Müller-Steinhagen, R. Henne, F.-J.Wetzel, "Einsatz von Brennstoffzellen für die Bordstromversorgung von Fahrzeugen", Proceedings of Fortschrittliche Energiewandlung und -anwendung, Stuttgart, 2003.

[22] S. Benson, Fuel cells - use with coal and other solid fuels, CCC / IEA Coal Research, no. 47, London: IEA Coal Research, The Clean Coal Centre, 2001.

[23] R. Henne, G. Schiller, N. H. Menzler, F.-J. Wetzel, H. Greiner, "Hochtemperatur-Brennstoffzellen - von der Komponentenentwicklung zum System", Proceedings of Jahrestagung des Forschungsverbunds Sonnenenergie, Berlin, 2004.

[24] L. Blum, W. A. Meulenberg, H. Nabielek, R. Steinberger-Wilckens, Worldwide SOFC Technology
Overview and Benchmark, Int. J. Appl. Ceram. Technol., doi:10.1111/j.1744-7402.2005.02049.x.

[25] X. Li, Principles of Fuel Cells, New York: Taylor \& Francis Group, 2006.

[26] P. Holtappels, U. Stimming, in: "Solid oxide fuel cells (SOFC)", in W. Vielstich (Ed.), Handbook of Fuel Cells, Chichester: Wiley, 2003.

[27] M. C. Williams, J. P. Strakey, S. C. Singhal, U.S. distributed generation fuel cell program, J. Power Sources, doi:10.1016/j.jpowsour.2004.01.021.

[28] N. F. Bessette, B. P. Borglum, H. Schichl, D. S. Schmidt, "SOFC-Technologie von Siemens: Auf dem Weg zur kommerziellen Nutzung", Siemens Power J., 10-13, 2001.

[29] R. A. George, N. F. Bessette, Reducing the manufacturing cost of tubular SOFC technology, $J$. Power Sources, PII: S0378-7753(97)02735-3.

[30] S. C. Singhal, Advances in solid oxide fuel cell technology, Solid State Ionics, PII: S01672738(00)00452-5

[31] R. Hiller, D. Schleitzer, Bewertung von Verfahren zur energetischen Nutzung von Biomasse mittels Brennstoffzellen, Technical Report, Gülzow: Fachagentur für Nachwachsende Rohstoffe e.V., 2001.

[32] C. Friedrich, Verfahrensentwicklung zur dezentralen Stromerzeugung mittels Biomasse-Vergasung und oxidkeramischer Hochtemperatur-Brennstoffzelle, Düsseldorf: VDI-Verlag, 2007.

[33] T. Kivisaari, P. Björnbom, C. Sylwan, B. Jacquinot, D. Jansen, A. de Groot, The feasibility of a coal gasifier combined with a high-temperature fuel cell, Chem. Eng. J., doi:10.1016/j.cej.2003.12.005.

[34] A. Lokurlu, Simulation der Oxidkeramischen Brennstoffzelle "SOFC" mit nachgeschalteten Gas- und Dampfturbinen-Kombi-Anlagen für verschiedene Brenngase, Düsseldorf: VDI-Verlag, 1999.

[35] A. Selimovic, Solid Oxide Fuel Cell Modelling for SOFC/Gas Turbine Combined Cycle Simulations, Technical Report, no. LUTMDN/TMVK-7039-SE, Lund: Lund Institute of Technology, 2000.

[36] C. Rechenauer, E. Achenbach, Dreidimensionale mathematische Modellierung des stationären und instationären Verhaltens oxidkeramischer Hochtemperatur-Brennstoffzellen, Technical Report, no. Jül 2752, Jülich: Forschungszentrum Jülich $\mathrm{GmbH}$, Institut für Energieverfahrenstechnik, 1993.

[37] N. Q. Minh, T. Takahashi (Eds.), Science and Technology of Ceramic Fuel Cells, Amsterdam: Elsevier, 1995.

[38] R. P. O’Hayre, S.-W. Cha, W. Colella, F. B. Prinz, Fuel Cell Fundamentals, New York: Wiley, 2006.

[39] S. C. Singhal, K. Kendall (Eds.), High Temperature Solid Oxide Fuel Cells, Oxford: Elsevier, 2003.

[40] A. V. Akkaya, Electrochemical model for performance analysis of a tubular SOFC, Int. J. Energy Res., doi: 10.1002/er. 1238 . 
[41] R. Bove, S. Ubertini, Modeling solid oxide fuel cell operation: Approaches, techniques and results, J. Power Sources, doi: 10.1016/j.jpowsour.2005.11.045.

[42] M. J. Carl, SOFC Modeling for the Simulation of Residential Cogeneration Systems (MSc Thesis), University of Victoria, 2008.

[43] M. Calì, M. G. L. Santarelli, P. Leone, Design of experiments for fitting regression models on the tubular SOFC CHP100kW : Screening test, response surface analysis and optimization, Int. J. Hydrogen Energy, doi: 10.1016/j.ijhydene.2006.05.021.

[44] P. Costamagna, L. Magistri, A. F. Massardo, Design and part-load performance of a hybrid system based on a solid oxide fuel cell reactor and a micro gas turbine, $J$. Power Sources, PII: S0378-7753(00)00668-6.

[45] A. Lazzaretto, A. Toffolo, F. Zanon, Parameter Setting for a Tubular SOFC Simulation Model, Trans. ASME, J. Energy Resour. Technol., doi:10.1115/1.1653752.

[46] P. Lisbona, L. M. Romeo, Enhanced coal gasification heated by unmixed combustion integrated with an hybrid system of SOFC/GT, Int. J. of Hydrogen Energy, doi:10.1016/j.ijhydene.2008.06.031.

[47] S. Campanari, Thermodynamic model and parametric analysis of a tubular SOFC module, J. Power Sources, PII:S0378-7753(00)00494-8.

[48] D. Cocco, V. Tola, Comparative Performance Analysis of Internal and External Reforming of Methanol in SOFC-MGT Hybrid Power Plants, Trans. ASME, J. Eng. Gas Turbines Power, doi:10.1115/1.2364009.

[49] V. Hacker, W. Sanz, M. Monsberger, H. Jericha, "High efficient SOFC/GT cycle", Proceedings of the 15th World Hydrogen Energy Conference, Yokohama, Japan, 2004.

[50] W. Zhang, E. Croiset, P. L. Douglas, M. W. Fowler, E. Entchev, Simulation of a tubular solid oxide fuel cell stack using AspenPlus ${ }^{\mathrm{TM}}$ unit operation models, Energy Convers.

Manage., doi:10.1016/j.enconman.2004.03.002.

[51] F. Müller, J. Brouwer, F. Jabbari, S. Samuelsen, Dynamic Simulation of an Integrated Solid Oxide Fuel Cell System Including Current-Based Fuel Flow Control, Trans. ASME, J. Fuel Cell Sci. Technol., doi:10.1115/1.2174063.

[52] C. Wang, M. H. Nehrir, A Physically Based Dynamic Model for Solid Oxide Fuel Cells, IEEE Trans. Energy Conver., doi:10.1109/TEC.2007.895468.

[53] P. Costamagna, E. Arato, P. L. Antonucci, V. Antonucci, Chem. Eng. Sci. 51 (1996) 3013-3018.

[54] R. Kandepu, L. Imsland, B. Foss, C. Stiller, B. Thorud, O. Bolland, Modeling and control of a SOFC-GT-based autonomous power system, Energy, doi:10.1016/j.energy.2006.07.034.

[55] F. Standaert, Analytical Fuel Cell Modelling and Exergy Analysis of Fuel Cells (PhD Thesis), Technische Universiteit Delft, 1998.

[56] R. Bove, P. Lunghi, N. Sammes, SOFC mathematic model for systems simulations - Part 2: definition of an analytical model, Int. J. Hydrogen Energy, doi:10.1016/j.ijhydene.2004.04.018.

[57] P. Costamagna, P. Costa, V. Antonucci, Micromodelling of solid oxide fuel cell electrodes, Electrochim. Acta, PII: S0013-4686(97)00063-7.

[58] J. Padulles, G. W. Ault, J. R. McDonald, An integrated SOFC plant dynamic model for power systems simulation, J. Power Sources, PII: S03787753(99)00430-9.

[59] C. O. Colpan, I. Dincer, F. Hamdullahpur, Thermodynamic modeling of direct internal reforming solid oxide fuel cells operating with syngas, Int. J. Hydrogen Energy, doi:10.1016/j.ijhydene.2006.10.059.

[60] M. Lemánski, J. Bedur, Parametrical analysis of a tubular pressurized SOFC, Arch. of Thermody., 25, 53$72,2004$.

[61] L. Magistri, R. Bozzo, P. Costamagna, A. F. Massardo, "Simplified versus detailed SOFC reactor models and influence on the simulation of the design point performance of hybrid systems", Proceedings of the ASME Turbo Expo 2002, Amsterdam, Netherlands, 2002.

[62] L. Pisani, G. Murgia, An Analytical Model for Solid Oxide Fuel Cells, J. Electrochem. Soc., doi:10.1149/1.2742812.

[63] P. Kuchonthara, S. Bhattacharya, A. Tsutsumi, Combinations of solid oxide fuel cell and several enhanced gas turbine cycles, J. Power Sources, doi:10.1016/S0378-7753(03)00740-7.

[64] W. Jiang, R. Fang, J. A. Khan, R. A. Dougal, Parameter setting and analysis of a dynamic tubular SOFC model, J. Power Sources, doi:10.1016/j.jpowsour.2006.06.086.

[65] P. Costamagna, K. Honegger, Modeling of solid oxide heat exchanger integrated stacks and simulation at high fuel utilization, J. Electrochem. Soc., doi:10.1149/1.1838904.

[66] S. Assabumrungrat, N. Laosiripojana, P. Piroonlerkgul, Determination of the boundary of carbon formation for dry reforming of methane in a solid oxide fuel cell, J. Power Sources, doi:10.1016/j.jpowsour.2005.12.010.

[67] W. Sangtongkitcharoen, S. Assabumrungrat, V. Pavarajarn, N. Laosiripojana, P. Praserthdam, Comparison of carbon formation boundary in different modes of solid oxide fuel cells fueled by methane, $J$. Power Sources, doi:10.1016/j.jpowsour.2004.10.009.

[68] Z. Zeng, K. Natesan, Corrosion of metallic interconnects for SOFC in fuel gases, Solid State Ionics, doi:10.1016/j.ssi.2003.11.026.

[69] I. Barin, F. Sauert, E. Schultze-Rhonhof, W. S. Sheng, Thermochemical Data of Pure Substances: Part I: Ag$K r, 2^{\text {nd }} E d$., Weinheim: VCH, 1993.

[70] S. Veyo, "Westinghouse Fuel Cell Combined Cycle Systems", Proceedings of Fuel Cells '96 Review Meeting, Morgantown, 1996. 
[71] S. Veyo, W. Lundberg, "Solid Oxide Fuel Cell Power System Cycles", Proceedings of International Gas Turbine \& Aeroengine Congress \& Exhibition, Indianapolis, 1999.

[72] M. Krumbeck, C. Huster, H. Mertikat, C. Jansen, "Betriebserfahrungen mit HochtemperaturBrennstoffzellen-Systemen", Proceedings of the Stationäre Brennstoffzellen, Heilbronn, 2003.

[73] S. Campanari, P. Iora, P., Definition and sensitivity analysis of a finite volume SOFC model for a tubular cell geometry, J. Power Sources, doi:10.1016/j.jpowsour.2004.01.043

[74] S. Campanari, Full Load and Part-Load Performance Prediction for Integrated SOFC and Microturbine Systems, Trans. ASME, J. Eng. Gas Turbines Power, doi: S0742-4795(00)01702-6.

[75] P. E. Campbell, J. T. McMullan, B. C. Williams, Concept for a competitive coal fired integrated gasification combined cycle power plant, Fuel, PII: S0016-2361(99)00228-8
[76] P. Leone, M. G. Santarelli, M. Calí, Model and Simulation of a SOFC CHP Plant Fuelled with Hydrogen, ECS Transactions, doi:10.1149/1.2729035.

[77] A. Weber, B. Sauer, A. C. Müller, D. Herbstritt, E. Ivers-Tiffée, Oxidation of $\mathrm{H}_{2}, \mathrm{CO}$ and methane in SOFCs withNi/YSZ-cermet anodes, Solid State Ionics, PII: S0167-2738(02)00359-4

[78] K. Sasaki, Y. Hori, R. Kikuchi, K. Eguchi, A. Ueno, H. Takeuchi, M. Aizawa, K. Tsujimoto, H. Tajiri, H. Nishikawa, Y. Uchidad, Current-Voltage Characteristics and Impedance Analysis of Solid Oxide Fuel Cells for Mixed $\mathrm{H}_{2}$ and $\mathrm{CO}$ Gases, J. Electrochem. Soc., doi:10.1149/1.1435357.

[79] K. D. Panopoulos, L. E. Fryda, J. Karl, S. Poulou, E. Kakaras, High temperature solid oxide fuel cell integrated with novel allothermal biomass gasification, Part I: Modelling and feasibility study, J. Power Sources, doi:10.1016/j.jpowsour.2005.12.024. 